\title{
Communication/Comunicação
}

\section{Phlebotomine sand flies (Diptera: Psychodidae: Phlebotominae) in the State of Pernambuco}

\author{
Flebotomíneos (Diptera: Psychodidae: Phlebotominae) no Estado de Pernambuco
}

\author{
Filipe Dantas-Torres ${ }^{1,2}$, Andrey José de Andrade ${ }^{3}$, Klaudia Emanuela Ramos Tenório ${ }^{4}$, José Dilermando \\ Andrade Filho ${ }^{5}$, Valdir de Queiroz Balbino ${ }^{4}$ and Sinval Pinto Brandão-Filho ${ }^{2}$
}

\begin{abstract}
Introduction: Phlebotomine sand flies are small insects of great medical relevance. This article presents an updated list of the phlebotomine sand flies occurring in the State of Pernambuco, Brazil. Methods: A review of literature published since the 1940s up to May 2010 was conducted and voucher material deposited in reference collections were studied. Results: A total of 37 phlebotomine species have previously been reported as occurring in Pernambuco, but the record of six species needs confirmation. Conclusions: This work provides an updated list of phlebotomine sand flies of Pernambuco, with some notes on their taxonomy, ecology, distribution and epidemiological relevance.
\end{abstract}

Key-words: Phlebotomine sand flies. Leishmaniases. Pernambuco.

\section{RESUMO}

Introdução: Flebotomíneos são pequenos insetos de grande importância médica e veterinária. Este artigo apresenta uma lista atualizada dos flebotomíneos que ocorrem no Estado de Pernambuco, Brasil. Métodos: Uma revisão da literatura publicada desde a década de 40 até maio de 2010 foi realizada e material testemunho depositado em coleções de referência foi estudado. Resultados: Um total de 37 espécies de flebotomíneos foram previamente relatadas como presentes em Pernambuco, mas o registro de seis delas necessita de confirmação. Conclusões: Esse trabalho fornece uma lista atualizada de flebotomíneos de Pernambuco, com algumas notas sobre a sua taxonomia, ecologia, distribuição e relevância epidemiológica.

Palavras-chaves: Flebotomíneos. Leishmanioses. Pernambuco.

Phlebotomine sand flies are small insects of great medical and veterinary relevance. In particular, they are vectors of Leishmania parasites, the causative agents of the leishmaniases, which are a group of diseases that affect thousands of people worldwide. In Brazil, the leishmaniases represent a major public health problem and their control seems to be far from reality. The Brazilian phlebotomine sand fly fauna is composed of over 230 species $^{1}$, representing one of the best-studied faunas in the world. Knowledge concerning the phlebotomine sand fly fauna is pivotal to providing baseline information for public health policy makers to development their leishmaniasis control programs.

1. Department of Public Health and Zootechny, University of Bari, Valenzano, Bari, Italy. 2. Department of Immunology,Aggeu Magalhães Research Center, Oswaldo CruzFoundation, Recife, PE, Brazil. 3. Department of Parasitology, Federal University of Minas Gerais, Belo Horizonte, MG, Brazil.4.Department of Genetics, Federal University ofPernambuco, Recife, PE, Brazil. 5. National and International Reference Center for Phlebotomine sand flies, René Rachou Research Center, Oswaldo Cruz Foundation, Belo Horizonte, MG, Brazil.

Address to: Dr. Filipe Dantas-Torres. DeptPublic Health andZootechny/UNIBA. Str. Prov. per Casamassima km 3, 70010 Valenzano, Bari, Italy. Dr. Sinval P. Brandão-Filho. Depto ${ }^{\circ}$ de Imunologia/CPqAM/FIOCRUZ, Av. Moraes Rego s/n, 50670-900 Recife, PE. Phone: 390805443839

e-mail: f.dantastorres@veterinaria.uniba.it; sinval@cpqam.fiocruz.br

Received in 13/05/2010

Accepted in 30/08/2010
During the past decade, several studies on phlebotomine sand flies occurring in the State of Pernambuco were conducted in areas of leishmaniasis endemicity ${ }^{2-11}$. These studies have provided new insights into the eco-epidemiology of leishmaniases in northeastern Brazil. Notwithstanding, the leishmaniases still represent a severe, expanding problem in Pernambuco. The objective of this article is to provide an updated list of the phlebotomine sand flies of Pernambuco. In addition, notes on taxonomy, ecology, geographical distribution and epidemiological relevance of the species found in this state are provided.

Pernambuco (northeastern Brazil) has an area of $98,311 \mathrm{~km}^{2}$ and an estimated population of $8,810,256$ inhabitants. The state's territory is politically divided in 184 municipalities (plus the island of Fernando de Noronha) distributed over five geographical regions. The metropolitan area of Recife (Região Metropolitana de Recife, RMR) represents the coastal region. It includes 14 municipalities and its vegetation predominantly consists of mangrove and Atlantic rainforest, with a mostly wet tropical climate. The forest area (Zona da Mata, ZM) represents the Atlantic rainforest region, although much of its primary vegetation has been destroyed, mainly for agricultural purposes. It includes 43 municipalities and has a wet tropical climate. The Agreste (A) includes 71 municipalities and constitutes an area of transition between the Atlantic rainforest and the Caatinga: a shrub steppe, with extensive patches of bare soil and rocks. The climate and vegetation are highly variable; some municipalities have landscape features related to the Atlantic rainforest, whereas others form part of the semi-arid region. The Sertão $(S)$ and Sertão do São Francisco (SSF) include 41 and 15 municipalities, respectively, and are situated in the semi-arid region, whose main biome is the Caatinga.

This study was based on a review of the literature regarding the phlebotomine sand flies found in Pernambuco. Data was compiled from several papers ${ }^{2-11}$ and reference textbooks ${ }^{1,12-14}$. Information on the phlebotomine sand flies of Pernambuco available at the Computer-Aided Identification Program for Phlebotomine sandflies of Americas (CIPA) database (http://cipa.snv.jussieu. fr) was also compiled. Abstracts presented in scientific meetings were not considered. Whenever needed, remarks on the taxonomy, distribution, ecology and vector role of the species are provided.

Phlebotomine sand fly specimens from Pernambuco available at the Centro de Referência Nacional e Internacional para Flebotomíneos (CRNIF) of the Centro de Pesquisas René Rachou (CPqRR); Belo Horizonte, Minas Gerais, Brazil, were examined. Accession numbers: 26984-26986, 26897, 26991, 26994, 49186, 49188, 49189, 49192, 49195, 49197, 49200-49202, 49210-49212. New locality records are shown in Table 1. The nomenclature of phlebotomine sand flies follows Galati ${ }^{1}$. 
TABLE 1 - Phlebotomine sand flies record for Pernambuco, northeastern Brazil.

\begin{tabular}{|c|c|}
\hline Species & Distribution \\
\hline Brumptomyia nitzulescui (Costa-Lima) & Igarassu \\
\hline Evandromyia cortelezzii (Brèthes) $)^{(1)}$ & Afogados da Ingazeira, Pedra, São José do Egito \\
\hline Evandromyia evandroi (Costa Lima \& Antunes) & Igarassu, Paudalho, Recife, Amaraji, Primavera, São Vicente Férrer \\
\hline Evandromyia lenti (Mangabeira) $)^{(1)}$ & Salgueiro, Serra Talhada, Triunfo \\
\hline Evandromyia sallesi (Galvão \& Coutinho) & Recife \\
\hline Evandromyia tupynambai (Mangabeira) & Paudalho, Goiana ${ }^{(2)}$, São Vicente Férrer \\
\hline Evandromyia walkeri (Newstead) & Paudalho, Amaraji, São Vicente Férrer \\
\hline Lutzomyia longipalpis (Lutz \& Neiva) & Itamaracá, Olinda, Paulista, Recife, Calumbi, Custódia, Exu, Floresta, Gravatá, Goiana ${ }^{(2)}$ \\
\hline Migonemyia migonei (França) & Primavera, Quipapá, Pesqueira, São Vicente Férrer \\
\hline Pintomyia fischeri (Pinto) & Jaboatão dos Guararapes, São Lourenço da Mata, Recife, Amaraji, São Vicente Férrer \\
\hline Pressatia choti (Floch \& Abonnenc) & Igarassu, Paudalho, Recife, São Vicente Férrer \\
\hline Sciopemyia fluviatilis (Floch \& Abonnenc) $)^{(1)}$ & Recife \\
\hline Sciopemyia servulolimai (Damasceno \& Causey) & Paudalho \\
\hline Trichopygomyia longispina (Mangabeira) & Igarassu, Paudalho \\
\hline Bichromomyia flaviscutellata (Mangabeira) & Recife \\
\hline Nyssomyia intermedia (Lutz \& Neiva) & $\begin{array}{l}\text { Jaboatão dos Guararapes, Moreno, Lagoa dos Gatos, Nazaré da Mata, Primavera, } \\
\text { Quipapá, Vitória de Santo Antão, Timbaúba }\end{array}$ \\
\hline Nyssomyia umbratilis (Ward \& Fraiha) & Recife \\
\hline Nyssomyia whitmani (Antunes \& Coutinho) & $\begin{array}{l}\text { Jaboatão dos Guararapes, Moreno, Paulista, São Lourenço da Mata, Igarassu, Paudalho, } \\
\text { Recife, Amaraji, Cortês, Nazaré da Mata, Primavera, Quipapá, Timbaúba, } \\
\text { Vitória de Santo Antão, Gravatá, São Vicente Férrer }\end{array}$ \\
\hline Psathyromyia aragaoi (Costa Lima) & Itamaracá, Igarassu, São Lourenço da Mata, Recife, Amaraji, Cortês \\
\hline Psathyromyia barrettoi barrettoi (Mangabeira) & Paudalho \\
\hline Psathyromyia brasiliensis (Costa Lima) & Paudalho, São Lourenço da Mata, São Vicente Férrer \\
\hline Psychodopygus amazonensis (Root) & Paudalho \\
\hline Psychodopygus ayrozai (Barretto \& Coutinho) & Paudalho \\
\hline Psychodopygus claustrei (Abonnenc, Léger \& Fauran) & Igarassu, Recife \\
\hline Psychodopygus complexus (Barretto \& Coutinho) & Paudalho, Recife, Amaraji, São Vicente Férrer \\
\hline Psychodopygus squamiventris (Lutz \& Neiva) $)^{(1)}$ & Igarassu, Paulista, Recife \\
\hline Psychodopygus wellcomei Fraiha, Shaw \& Lainson ${ }^{(1)}$ & Igarassu \\
\hline Viannamyia furcata (Mangabeira) & Recife, Goiana ${ }^{(2)}$, São Vicente Férrer \\
\hline Micropygomyia capixaba (Dias, Falcão, Silva \& Martins) & Paudalho, São Vicente Férrer \\
\hline Micropygomyia micropyga (Mangabeira) & Paulista ${ }^{(2)}$, Lagoa dos Gatos \\
\hline Micropygomyia oswaldoi (Mangabeira) & Itamaracá, Jaboatão dos Guararapes, Recife, Goiana ${ }^{(2)}$, Floresta, São Vicente Férrer \\
\hline Micropygomyia peresi (Mangabeira) $)^{(1)}$ & $\begin{array}{l}\text { Macaparana, Nazaré da Mata, Afogados da Ingazeira, São José do Egito, Bezerros, } \\
\text { Bom Jardim, Caruaru, Pedra, Sertânia, Taquaritinga do Norte, Gravatá, Lagoa dos Gatos }\end{array}$ \\
\hline Micropygomyia quinquefer (Dyar) & $\begin{array}{l}\text { Paudalho, Amaraji, Macaparana, Nazaré da Mata, Bezerros, Pedra, Cortês, } \\
\text { São Vicente Férrer, Sertânia }\end{array}$ \\
\hline Micropygomyia schreiberi (Martins, Falcão \& Silva) & $\begin{array}{l}\text { Itamaracá, Jaboatão dos Guararapes, Moreno, Paudalho, Paulista, Recife, } \\
\text { Lagoa dos Gatos, São Vicente Férrer }\end{array}$ \\
\hline
\end{tabular}

In total, 37 phlebotomine sand fly species belonging to 14 genera have previously been reported in Pernambuco, but the record of six species needs confirmation (Table 1). Phlebotomine sand flies have been collected in 33 (18\%) municipalities, being the fauna of Recife the most well studied. Aguiar \& Medeiros ${ }^{14}$ and Galati ${ }^{1}$ cited 26 and 30 species for Pernambuco, respectively. In comparison with other northeastern Brazilian states, the phlebotomine sand fly fauna of Pernambuco is smaller in terms of species diversity than Maranhão and Bahia, but is more diverse than that of Alagoas, Ceará, Paraíba, Piauí, Rio Grande do Norte and Sergipe ${ }^{1,14}$.

The presence of six species (Ev. cortelezzii, Ev. lenti, Ps. squamiventris, Ps. wellcomei, Sc. fluviatilis, Mi.peresi) in Pernambuco needs confirmation. The drawings of Lucena ${ }^{15}$ raise doubts regarding whether he was studying Ev. cortelezzii or Ev. sallesi. Martins et $\mathrm{a}^{12}$ recorded Ev. lenti in Pernambuco, citing Mamanguape as the locality. 
One of the authors (JDAF) reexamined this material (CRNIF accession number: 26967) and the slide was labeled as 'MamanguapePB', which is in the State of Paraíba. Sciopemyia fluviatilis was reported once in Pernambuco, but it is thought to be restricted to northern Brazil and French Guiana ${ }^{1}$. Reports of Ps. squamiventris by Lucena and colleagues are likely a misidentification of Ps. claustrei or Ps. complexus ${ }^{6}$. Micropygomyia peresi was reported in Pernambuco, but no voucher specimen was available for confirmation ${ }^{13}$.

Pernambuco is represented by two main biomes: Atlantic rainforest and Caatinga. The limited published data does not permit an in-depth analysis of the species diversity in each region of Pernambuco. However, considering the published data and authors' personal experiences, the coastal region, the Atlantic rainforest region and the inland region are home to the largest number of phlebotomine sand fly species in this state. The semi-arid region is the least explored and, so far, only five species have been reported in this region, which appears to be an underestimation of its species diversity. Indeed, the Caatinga is a hostile environment for species that are not adapted to survive in semi-arid conditions. Lutzomyia longipalpis is adapted to such extreme conditions and for this reason visceral leishmaniasis is widespread in the inland and semi-arid regions of Pernambuco. Migonemyia migonei is a suspected vector of Leishmania infantum (syn. L. chagasi) in São Vicente Férrer, where cases of visceral leishmaniasis have been reported, but $\mathrm{Lu}$. longipalpis has never been identified ${ }^{10}$.

Among the species identified in Pernambuco, approximately 10 are regarded as proven or putative vectors of Leishmania sp. Indeed, most of the epidemiologically important species are widespread, indicating that they are well adapted to different biomes. Likewise, the wide distribution of certain species (e.g., Lu. longipalpis and $N y$. whitmani) indicates that most of the population of Pernambuco is at risk of Leishmania spp. infection.

The vectors of $L$. braziliensis in Pernambuco might vary according to geographical region. In a focus in the southern part of the Atlantic rainforest region, $N y$. whitmani is considered to be the most important vector. It is the most abundant species in the domicile and peridomicile and has been found naturally infected by L. braziliensis in a focus of cutaneous leishmaniasis in Amaraji. This species is highly adapted to modified environments, usually found in animal shelters and plantations, but it is seldom found in forested areas ${ }^{4,10}$. Martins et al ${ }^{12}$ included Gravatá, Nazaré da Mata and Quipapá in the distribution of Ny. whitmani, but without further details. Nyssomyia intermedia, another species of public health concern, has been collected in low numbers in areas of $L$. braziliensis endemicity in Pernambuco ${ }^{11}$, but so far there is no consistent data on its participation in the transmission of this parasite in this state. Although Martins et a ${ }^{12}$ included Nazaré da Mata in the distribution of Ny. intermedia in Pernambuco, they provided no further details.

In a military training area located in the northern Atlantic rainforest, where outbreaks of cutaneous leishmaniasis have been reported, $N y$. whitmani represented less than $1 \%$ of the population, rather Ps. complexus and Pr. choti were the most abundant species ${ }^{4}$. Females of Pr. choti, Sc. sordellii, Ps. amazonensis and Tr. longispina from Paudalho were dissected but no flagellate was found ${ }^{4}$. BrandãoFilho et $\mathrm{al}^{2}$ reported Ps. wellcomei in Paudalho, but they were actually observing Ps. complexus ${ }^{4}$. Several Ps. complexus females from Paudalho were dissected and flagellates were seen in one of them, but an attempt to isolate the parasite failed ${ }^{4}$.
In a cutaneous leishmaniasis focus in the northern inland region of Pernambuco, where Ny. whitmani is present at low density, Mi. migonei is the suspected vector in the domicile and peridomicile and Ps. complexus in forested areas. In Pernambuco, $N y$. whitmani is well adapted to environments modified by man (e.g., for agricultural purposes) and in some areas, the cycle of transmission of L. braziliensis might occur in the peridomicile. Psathyromyia naftalekatzi is only species described from Pernambuco, based on specimens collected in a chicken crop in Amaraji, where cutaneous leishmaniasis is endemic ${ }^{3}$. This species has been collected in areas of L. braziliensis endemicity ${ }^{4,10}$, but so far there is no evidence supporting its vector role.

The leishmaniases are still causing a heavy, yet underestimated burden in Brazil. In Pernambuco, they are an expanding problem and improving current knowledge of their epidemiology is the key towards their control. Indeed, further research on phlebotomine sand fly ecology and leishmaniasis epidemiology in Pernambuco is needed. It is important to know the seasonality of vector species, whether they are spreading and how could this impact on leishmaniasis epidemiology. This list will provide the foundation for the development of new projects, which in turn could help public health authorities strength their control programs in Pernambuco.

\section{ACKNOWLEDGMENTS}

The authors would like to thank Ana Paula Martins Oliveira (UFMG) for providing us with Lucena's early pioneer papers on the phlebotomine sand flies of Pernambuco. The authors are also to CAPES, CNPq, FACEPE, FAPESP and FIOCRUZ for supporting many projects related to sand flies and eco-epidemiology of leishmaniasis in Pernambuco during the past 15 years.

\section{CONFLICT OF INTEREST}

The authors declare that there is no conflict of interest.

\section{REFERÊNCIAS}

1. Galati EAB. Classificação de Phlebotominae. In: Rangel EF, Lainson R, editors Flebotomíneos do Brasil. Rio de Janeiro: Fundação Oswaldo Cruz; 2003. p. 23-51.

2. Brandão-Filho SP, Brito MEF, Martins CA, Sommer IB, Valença HF, Almeida FA, et al. Leishmaniose tegumentar americana em centro de treinamento militar localizado na zona da mata de Pernambuco, Brasil. Rev Soc Bras Med Trop $1998 ; 31: 575-578$

3. Falcão AL, Andrade-Filho JD, Almeida FA, Brandão-Filho SP. Lutzomyia naftalekatzi, a new species of phlebotomine sand fly (Diptera: Psychodidae) from Zona da Mata region, Pernambuco, Brazil. Mem Inst Oswaldo Cruz 2000; 95:843-848.

4. Andrade MS, Valença HF, Silva AL, Almeida FA, Almeida EL, Brito MEF, et al. Sandfly fauna in a military training area endemic for American tegumentary leishmaniasis in the Atlantic Rain Forest region of Pernambuco, Brazil. Cad Saude Publica 2005; 21:1761-1767.

5. Balbino VQ, Andrade MS, Sonoda IV, Abreu-Coutinho IV, Marcondes CB Shaw JJ, et al. Sand flies (Diptera: Psychodidae) in Pernambuco State, northeastern Brazil: the presence of species incriminated as vectors of cutaneous leishmaniasis in the Amazon region in Pernambuco State, northeastern Brazil. Zootaxa 2005; 1078:25-32.

6. Balbino VQ, Coutinho-Abreu IV, Sonoda IV, Marques-da-Silva W, Marcondes CB Phlebotomine sandflies (Diptera: Psychodidae) of the Atlantic forest in Recife, Pernambuco state, Brazil: the species coming to human bait, and their seasonal 
and monthly variations over a 2-year period. Ann Trop Med Parasitol 2005; 99:683-693.

7. Balbino VQ, Coutinho-Abreu IV, Sonoda IV, Melo MA, Andrade PP, Castro JA, et al. Genetic structure of natural populations of the sand fly Lutzomyia longipalpis (Diptera: Psychodidae) from the Brazilian northeastern region. Acta Trop 2006; 98:15-24.

8. Silva DF, Vasconcelos SD. Phlebotomine sandflies in fragments of rain forest in Recife, Pernambuco State. Rev Soc Bras Med Trop 2005; 38:264-266.

9. Dantas-Torres F, Almeida FA, Brandão-Filho SP. Phlebotomine sandflies of an urban focus of visceral leishmaniosis, Pernambuco State. Rev Patol Trop 2006; 35:157-160.

10. Carvalho MR, Lima BS, Marinho-Júnior JF, Silva FJ, Valença HF, Almeida FA, et al. Phlebotomine sandfly species from an American visceral leishmaniasis area in the Northern Rainforest region of Pernambuco State, Brazil. Cad Saude Publica 2007; 23:1227-1232.

11. Silva O, Sousa ME, Santos FA, Silva P, Gazin P. La leshmaniose tégumentaire américaine dans la région sucrière du Pernambouc, Nord-Est du Brésil. Santé 2000; 10:123-126.

12. Martins AV, Williams P, Falcão AL. American sand flies (Diptera: Psychodidae, Phlebotominae). Rio de Janeiro: Academia Brasileira de Ciências; 1978.

13. Young DG, Duncan MA. Guide to the identification and geographic distribution of Lutzomyia sand flies in Mexico, the West Indies, Central and South America (Diptera: Psychodidae). Gainesville: Associated Publishers; 1994.

14. Aguiar GM, Medeiros VM. Distribuição regional e habitats das espécies de flebotomíneos do Brasil. In: Rangel EF, Lainson R, editors. Flebotomíneos do Brasil. Rio de Janeiro: Fundação Oswaldo Cruz; 2003. p. 207-255.

15. Lucena DT, Oliveira MHCC, Leal MCA. Variação mensal dos flebotomíneos (Diptera: Psychodidae) de Igarassu, PE. Cad Ômega, Sér biol 1984; 1:19-27. 